\title{
Development of the STEM College-Going Expectancy Scale for High School Students
}

\author{
Youn Joo $\mathrm{Oh}^{1}$, Yueming $\mathrm{Jia}^{1}$, Bernadette Sibuma ${ }^{1}$, Mhora Lorentson ${ }^{2} \&$ Frank LaBanca ${ }^{3}$ \\ ${ }^{1}$ Leadership for Learning Innovation, Teaching and Learning Division, Education Development Center, Inc., Waltham, \\ MA, USA \\ ${ }^{2}$ Center for Collaborative Evaluation and Strategic Change, EDUCATION CONNECTION, Litchfield, CT, USA \\ ${ }^{3}$ Center for 21 st Century Skills, EDUCATION CONNECTION, Litchfield, CT, USA
}

Correspondence: Youn Joo Oh, Leadership for Learning Innovation, Teaching and Learning Division, Education Development Center, Inc., 43 Foundry Avenue, Waltham, MA 02453, USA. Tel: 617-618-2943. E-mail: yjoooh@edc.org

Received: April 1, 2013

Accepted: April 23, 2013

Online Published: May 2, 2013

doi:10.5430/ijhe.v2n2p93

URL: http://dx.doi.org/10.5430/ijhe.v2n2p93

\begin{abstract}
The STEM College-Going Expectancy Scale (STEM CGES) was developed and validated in two studies conducted during 2010 and 2011. The STEM CGES is a self-report instrument measuring college-going expectancy, specifically for science, technology, engineering, and mathematics (STEM) domains. In Study 1, 95 students in an urban high school completed an 11-item online questionnaire to measure college-going expectancy in STEM domains. Exploratory factor analysis (EFA) retained 6 out of the 11 items for inclusion. In Study 2, Confirmatory Factor Analysis (CFA) used data collected from 658 students in 31 urban, suburban, and rural high schools. The results provide strong evidence that the STEM CGES is a valid and reliable instrument for measuring college-going expectancy for STEM domains.
\end{abstract}

Keywords: College-going expectancy, Instrument development, Survey research, Factor analysis, STEM

\section{Introduction}

\subsection{Assessing High School Student Perception of Capability in STEM areas}

During recent years, there has been a marked need and continuous research efforts to gain a better understanding of the impact of adolescents' decision-making processes on career and educational planning and performance (Betz, 2007; Bandura, Barbaranelli, Caprara, \& Pastorelli, 2001). Likewise, the continuing lack of gender and ethnic diversity in STEM professions has been well documented and researched (Watt, Shapka, Morris, Durik, Keating, Eccles, 2012; Syed, Azmitia, \& Cooper, 2011; Chemers, Zurbriggen, Syed, Goza, \& Bearman, 2011). For instance, Riegle-Crumb and colleagues (Riegle-Crumb, Moore, \& Ramos-Wada, 2011) found that Black and Hispanic male adolescents aspire to similar levels of science and math careers as do White males but are consistently less successful as evidenced by the percentage of minority students and White males who end up in these professions.

The relationship between decision making and long-term planning is of particular concern to educators, practitioners, and policy makers who seek more effective methods and tools to assess the factors that influence adolescents' decisions and capabilities to attend college and succeed in science, technology, engineering, and math (STEM) domains at the college level. Researchers have found that students' educational pathways become apparent between the eighth and tenth grade (Gibbons \& Borders, 2010; Witkow \& Fuligni, 2011). It is of critical importance to identify these factors early, as many career and educational plans are made well before high school graduation. In fact, some college preparation programs that demonstrate success for transition to college begin in early adolescence (Bergin, Cooks \& Bergin, 2007; Oesterreich, 2000). Towards this end, the current study tested, developed and validated an instrument to assess high school students' belief in their capability to attend college to study science, technology, engineering, or mathematics (STEM) and persist in college activities successfully in the future. 


\subsection{Hypotheses}

This study used an adapted version of Gibbons' (2005) College-Going Self-Efficacy Scale (CGSES) to assess general college-going self-efficacy. The CGSES was created to measure high school student self-efficacy related to college-going experiences in student capability, decision-making skills, family-related issues and financial issues. Based on prior research (e.g., Horn \& Nunez, 2000; Warburton, Bugarin, Nunez, \& Carroll, 2001) that shows how success in college is related to an individual's beliefs about their ability to both get into and stay in college, the CGSES scale contained two subscales: college attendance and college persistence.

We used Expectancy-Value theory (Eccles \& Wigfield, 1995; Eccles \& Wigfield, 2002; Wigfield \& Eccles, 2000) as the theoretical framework to develop items measuring high school student's college-going expectancies for success and ability beliefs in STEM. Particularly, we focused on the development of items that examined student capability and decision-making skills. We hypothesized that high school students perceive their STEM college-going capability in terms of ability beliefs and expectancies for success that are domain specific. The following hypotheses guided our study: 1. High school students perceive that STEM college-going capability is domain-specific. 2. High school students perceive STEM college-going capability in terms of both ability beliefs and expectancies for success.

\subsection{College-Going Scales}

To date, very few scales have been developed to measure college-going expectancy as related to beliefs about one's future ability to perform a task in a specific domain. However, a number of scales have been developed to assess college-going self-efficacy, including the College Self-Efficacy Instrument (Solberg, O'Brien, Villareal, Kennel, \& Davis, 1993), the Middle School Career Decision-Making Scale (Fouad \& Smith, 1997), the Academic Milestones Scale (Nauta, Epperson, \& Kahn, 1998), the Educational Degree Behaviors Self-Efficacy Scale (Gloria, Kurpius, Hamilton, \& Wilson, 1999), and the College-Going Self-Efficacy Scale ( Gibbons \& Borders, 2010).

These scales were designed primarily to assess students already in college, and none were designed specifically for STEM areas. Previous research has shown that scales developed to assess general expectancies for success, without regard to a particular domain, may not accurately measure college-going expectancy. Thus, the use of existing college-going self-efficacy scales cannot provide an accurate measure of the relationship between college-going expectancy and college attendance and persistence in STEM-related areas. Given the difference in focus (i.e., the task-specific nature of self-efficacy and domain-specific nature of expectancies), it is critical to design a scale that assesses students' expectancy to go to college more specifically in terms of STEM domains.

\subsection{Domain- and Task-Specificity}

The domain- and task- specificity of an item or construct is critical to consider when examining a student's college-going expectancy or self-efficacy. Recent research has provided ample evidence of domain-specific patterns of student motivation and behavior (Jacobs, Lanza, Osgood, Eccles, \& Wigfield, 2002; Pintrich, 2003). Bandura (1986) considers judgments of self-efficacy to be task-specific and states that "ill-defined global measure of perceived self-efficacy or defective assessments of performance will yield discordances" (p. 397). In other words, an individual's perceived self-efficacy is highly dependent on the specific task and the context of the situation (e.g., "I am certain that I can understand the most difficult material presented in texts" (Pintrich, Smith, Garcia, \& McKeachie, 1991, p. 13), rather than on a global sense of self-efficacy (e.g., "I am a good student"). In fact, Pajares (1996) found that efficacy has been typically measured at the task-specific level. However, in terms of expectancies for success, Wigfield and Eccles (2000) stated that expectancies have been largely measured by domain (e.g., "I will do well in math this year") rather than by task (e.g., "I'm confident I can do an excellent job on assignments and tests") (Marsh, Hau, Artelt, Baumert, \& Peschar, 2006, p. 358). Specifically, they found that children and adolescents can clearly distinguish between different ability beliefs and values; however, confirmatory factor analyses (CFAs) revealed that these children's and adolescents' ability beliefs and expectancies loaded together, such that responses to ability belief questions and expectancy questions were highly related. Therefore, the issues of domain- and task-specificity must be considered when examining students' expectancies or self-efficacy.

In general, beliefs about one's ability greatly impact academic achievement, goal setting and the use of learning strategies (Marsh et al., 2006). Indeed, Pajares and Miller (1995) determined that student confidence to solve math problems was a more powerful predictor of performance than either confidence in performing math-related tasks (in general) or in succeeding in math-related courses. In a similar study, Pajares and Johnson (1994) found that self-efficacy in writing skills was a stronger predictor of holistically-asessed essay scores than was self-efficacy in writing tasks. Self-efficacy appears to vary in terms of the specific domain or task undertaken. Thus it is critical to utilize assessments that are both task- and domain- specific when investigating self-efficacy. 


\subsection{Motivation and Achievement}

Although academic achievement is an important factor for gaining entry into college to pursue careers in STEM, an adolescent's continued motivation and attitude towards work in science and math as high school progresses is also important. According to Jacobs (2005), motivational research has shown that individuals who have high self-concepts of ability (i.e., ability beliefs) in math, science, and technology are generally more likely to select math and science courses and careers. Here, self-concept is defined as belief in one's capabilities and characteristics related to academic and social performance. Similarly, intrinsic values that students place on specific subjects have been shown to influence educational and career plans. Other researchers have examined these constructs in terms of attitudes, noting differences in aspiration based on race and gender (Riegle-Crumb et al., 2011).

Using the Expectancy-Value Theory (Eccles \& Wigfield, 1995; Eccles \& Wigfield, 2002; Wigfield \& Eccles, 2000) as a framework, current evidence suggests that a student's expectancy for success influences the decision to pursue study or work in a certain domain. Specifically, Expectancy-Value Theory suggests that students' motivation to achieve in any particular subject is a combination of their expectancy (expectancies for success and ability beliefs) and the subjective value that they place on that subject. Expectancies for success are defined as one's beliefs about how well he or she will perform in the future on a task in some domain (e.g., 'Can I do this task?'; Eccles \& Wigfield, 2002, p. 110). To measure expectancies for success, we can inquire about one's beliefs in his or her abilities on a future task. Ability beliefs are defined as domain-specific beliefs about a person's personality, identity, academic ability, and social competence (Wigfield \& Eccles, 2000). Measurements of expectancy then focus on a person's beliefs related to a future task while also focusing on his or her ability beliefs on current tasks.

The expectancy-value framework's other construct of task value is determined by the external characteristics of the task itself, that is, by the broader needs, goals, and value orientation of the individual ('Why should I do this task?'; Eccles, 1983a). Task value has been researched in terms of intrinsic value (e.g., interest), utility value, and attainment value measures. Deci and Ryan (1985), and Wigfield and Eccles (1992) conceptualized value theory with four constructs: attainment value, intrinsic value, utility value, and cost. Attainment value is defined as the importance of doing a task. Intrinsic value is defined as the enjoyment that a person gains when he or she is engaged in a task. Utility value is defined as the degree to which the task is valuable in accomplishing career or academic goals. Cost is described as lost opportunities that occur as a result of participation in a particular task. According to Eccles and Wigfield $(1995,2002)$, the subjective value of a task is positively correlated with motivation and performance. That is, the more a student values a certain task, the more motivated they will be to engage in the task and the more likely they will be to perform well in that specific task.

A student's motivation to achieve in any particular subject is largely predicted by his or her expectancies for success in the task (Wigfield, Tonks, \& Klauda, 2009). Expectancies for success and ability beliefs are often associated with self-perception of task-specific abilities (Schunk et al., 2007). If a student perceives herself to have a high ability for a specific task or in some domain, she expects to do well in that task or domain, either in the future or in the present (ability beliefs); likewise, if a student perceives himself to have low ability for a specific task or in some domain, he expects to do poorly in that task or domain. Contrastingly, subjective task value is determined by characteristics of a task itself, that is, by the broader needs, goals, values, and motivational orientations of the individual, and the affective memories associated with similar tasks in the past. According to Schunk and colleagues (2007), expectancy is closely tied to achievement and cognitive engagement while value beliefs are indicative of decision-making behavior that could lead to future achievement opportunities. Therefore, an individual's expectancies may predict present engagement or immediate performance, whereas one's subjective task values may be less variable and predict future decision-making. Schunk, Pintrich, and Meece (2007) determined that students' perceptions of their ability and expectancies for success were the strongest predictors of subsequent grades in mathematics and English, and were strong predictors of both learners' effort and persistence in these domains.

Research using the expectancy-value framework has found that expectancies for success are strong predictors of students' academic achievement (Ormrod, 2006; Pintrich \& Schunk, 2002; Shell, Colvin, \& Bruning, 1995; Wigfield, 1994; Zimmerman, 2000). Specifically, ability beliefs can predict the number of math and science courses taken in high school (Simpkins, Davis-Kean, \& Eccles, 2006; Byars-Winston \& Fouad, 2008). Although literature suggests distinct constructs, Wigfield and Eccles (2000) have found that ability beliefs and expectancy beliefs are indistinguishable empirically.

While expectancies for success refer to one's beliefs about his or her ability to do well on a future task in specific domain whereas, ability beliefs pertain to domain-specific beliefs about a person's personality, identity, academic ability, and social competence (Eccles, 1983a). This construct of ability belief is similar to Bandura's self-efficacy in 
that both deal with a person's perception of his or her capabilities (Schunk, Pintrich, \& Meece, 2008). Self-efficacy refers to one's ability belief to synthesize and carry out certain actions in order to achieve goals (Bandura, 1997). It is often referred to in regards to one's perception of his or her ability to succeed or complete a task in the short-term which, cumulatively, influences career and academic decisions in the long-term. However, unlike ability beliefs in expectancy-value theory, self-efficacy is a more situation-specific judgment of competence in a particular domain to carry out certain behavioral actions and cognitive skills and eventually perform the task successfully (Bong, 2001; Bong \& Clark, 1999). The characteristics of self-efficacy include (a) performance capabilities, (b) domain specificity, (c) sensitivity to contextual changes, and (d) future performance predictors (Zimmerman, 2000). Self-efficacy describes an individual's beliefs in his or her performance on tasks rather than his or her feelings about personal qualities. Self-efficacy is multidimensional in form; it changes depending on the domain of a task. This means that a person's self-efficacy presents a variety of beliefs of his or her capabilities based on judgment of different functions of a domain in relationship to his or her abilities. Furthermore, self-efficacy sensitively responds to the context of a task. According to Bandura (1986), self-efficacy beliefs are the most influential factors in an individual's decision to initiate and persist in a particular behavior and have positive effects on outcomes across a variety of domains, including academic performance, achievement, and career success. Further, outcome expectations depend on self-efficacy judgments. For instance, if a student judges that she currently has high efficacy in accomplishing a math-related to task, then she is more likely to have high expectations for future success in the task.

Self-efficacy has been found to be strongly predictive of success in college (Majer, 2009; Gore, 2006; Eccles \& Wigfield, 1995; Pintrich \& Schunk, 2002). For instance, Pajares and Schunk (2001) suggested that academic self-efficacy explains approximately a quarter of the variance in the prediction of academic outcomes beyond that of instructional influences. Self-efficacy influences an individual's sustained effort, persistence, and aspirations (Caprara, Vecchione, Allesandri, Gerbino, \& Barbranelli, 2011), course selection (Britner \& Pajares, 2006), academic continuance and achievement (Britner \& Pajares, 2006), college performance and persistence (Gore, 2006; Robbins, Lauver, Le, Davis, Langley, \& Carlstrom, 2004), GPA (Robbins et al., 2004), academic aspirations (Bandura et al., 2001), and career trajectories across domains and age levels (Bandura, Barbaranelli, Caprara, \& Pastorelli, 1996; Bandura et al., 2001; Britner \& Pajares, 2006; Gore, 2006). Moreover, Pajares and Schunk (2001) suggested that academic self-efficacy explains approximately a quarter of the variance in the prediction of academic outcomes beyond that of instructional influences. In general, the higher a person's perceived self-efficacy to fulfill an occupational or educational role, the more likely that individual is to pursue and persist in that particular area.

Wigfield and Eccles (2000) determined that ability beliefs and expectancies for success are indistinguishable empirically. Thus, we hypothesized that an individual's ability beliefs and expectancy for success in a domain will be highly correlated. Likewise, both constructs were used for the theoretical framework to develop a STEM-focused college-going expectancy scale. However, unlike ability beliefs and expectancies, which are often measured with regards to specific domains, measures of self-efficacy have been more task-specific in nature.

\section{Scale Development Process}

To create the College-Going Expectancy Scale (CGES) in STEM, we used multiple measurement and development processes. First, the original items in the College-Going Self-Efficacy Scale developed by Gibbons (2005) were field tested and revised based on the results of exploratory factor analysis (EFA); second, a literature review was conducted and used to further revise the items; third, the newly revised items were examined through a focus group with STEM educational experts and high school students. An 11-item STEM college-going expectancy scale was tested with a small set of students for EFA in a pilot study. A revised 6-item scale was then tested with a large group of students for confirmatory factor analysis (CFA).

\subsection{Initial Field Testing}

During 2010, a group of 114 Latino high school students in Southern California were administered the draft instrument to explore the validity and reliability of the CGSES. The original CGSES instrument contained 30 items. Because current study focuses on the impact of college-going experiences in student capability and decision-making skills, items related to family and financial issues were excluded. After completion of exploratory factor analysis, we selected 5 out of 14 items in the CGSES attendance and 5 out of 16 items in the CGSES persistence.

\subsection{Literature Review}

As part of the development process, a thorough literature review was conducted regarding motivation theories and studies. Based on the review, the language and content of the existing initial ten survey items was revisited to more rigorously identify high school student ability beliefs and expectancies for success related to college-going 
experiences in STEM. The items were also modified to identify behavioral actions and decision-making skills used to accomplish future tasks. The modified items were developed to identify students' perceptions of their capability to accomplish future tasks rather than their intentions for college attendance and persistence. Nine items were chosen out of 10. One item was deleted as it was determined to more appropriately measure task-related interest. The items were also revised for clarity and readability. At that point, the scale consisted of 9 total items: 5 Attendance items and 4 Persistence items.

\subsection{Focus Group with Experts}

Nine STEM education experts, including higher education faculty, high school faculty, including math and science department chairs, and science education specialists, were invited to a 45-minute focus group interview in February of 2011 to review the scale. The focus group was guided by the following questions: (1) Does the overall scale include the essential elements of student college-going self-efficacy in STEM? (2) Is each item clearly linked to students' college-going self-efficacy in STEM? (3) Does each item clearly communicate the intended meaning? And finally, (4) Is the language of each item both clear and concise? The focus group brought about the creation of two new items measuring students' beliefs in the ability to get good grades in high school math classes and in earning a college degree in STEM-related areas. Language and content of the items were modified to enhance student understanding and clarity.

\subsection{Focus Group Interview with Students}

Additionally, in March of 2011, a second focus group interview was conducted with 11 Connecticut high school students to assess the clarity and understanding of the 11-item in the scale. Based on the discussion in the student focus group, all 11 items were retained and the language and content were revised again.

\subsection{Field Testing}

The resulting 11-item scale generated from the expert reviews and focus groups was tested in a study with 95 urban high school students in Connecticut. The most valid items and factors in the scale were identified using exploratory factor analysis (EFA). Subsequently, an updated version of the scale with 6 total items was tested with 658 high school students utlizing confirmatory factor analysis (CFA) to validate the structure of the scale.

\section{Study 1: Exploratory Factor Analysis (EFA)}

\subsection{Method}

Exploratory factor analysis (EFA) was conducted with the College-Going Expectancy in STEM measure to explore the dimensionality of the measure and identify items and factors that did not fit into the measure.

\subsubsection{Participants}

Participants included 95 high students who studied in one urban high school: 53\% were female and the self-reported ethnic composition was 73\% White, 3\% African-American, 6\% Asian-American, 14\% Hispanic American, and 4\% other.

\subsubsection{Procedures}

In June 2011, all participants were administered the 25-minute online survey following appropriate parent consent and student assent protocols. A study research associate was available to answer questions raised by the participants.

\subsubsection{The STEM College-Going Expectancy Measure}

The measure included 11 items assessing students' belief in their capability to attend and succeed in college studying STEM: 8 items focused on students' expectancy for success in getting into colleges to study STEM; 3 items focused on students' belief in their capacity to get good grades in high school science, math, and technology-related courses. Students responded to the items using a 7-point Likert scale ranging from 1 (not at all true) to 7 (very true).

\subsubsection{Analytic Strategy}

Three analytic steps were taken for the analyses. The first step was to identify the number of the factors in the measure. The factor number was decided based on the examination of scree plot, eigenvalues, the goodness of fit of various factor models, and parallel analysis. Model fit indices such as standardized root mean square residual (SRMR), root mean square error of approximation (RMSEA), comparative fit index (CFI), and the Tucker-Lewis index (TLI) were used as the criteria. The value of Chi-square and $\chi^{2} / \mathrm{df}$ were also provided. (Note 1)

The second step was to assess the quality of items within each factor. The items were judged based on two criteria: acceptable loading and no cross loading. Loading size larger than .60 was considered to be high and larger than .45 
was considered acceptable. Loading size larger than .35 in over one factor was considered as cross-loading (Lackey, Sullivan, \& Pett, 2003; Silvera, Martinussen, \& Dahl, 2001; Tabachnick \& Fidell, 2001). The last step was to examine the quality of factors. Factors with less than 2 items indicated a poor quality (Lackey et al., 2003). Finally, items and factors with poor quality were eliminated and the three EFA steps were repeated with the remaining items.

Mplus Version 6.1 (Muthen \& Muthen, 1998-2010) was used to generate scree plot, eigenvalues, and the model fit indices. Although Likert scale variables are categorical in nature, the seven categories were treated as continuous variables (Johnson \& Creech, 1983). Maximum Likelihood estimation was used with a correlation matrix. The potential factors in the measure were assumed to correlate with each other, and thus oblique rotation was applied to reach an interpretable solution. Parallel analysis was conducted with FACTOR Version 8.02 (Lorenzo-Seva \& Ferrando, 2011).

\subsection{Results}

\subsubsection{Factorability of the Correlation Matrix}

The ratio of participants to items for the EFA was close to 9:1, which is slightly lower than Gorsuch's (1983) suggestion for minimum ratio of 10:1. However, Bartlett's test of sphericity revealed that the correlation in the matrix of the sample was significantly different from 0 . Furthermore, the size of Kaiser-Meyer-Oklin measure of sampling adequacy (KMO) for this sample was .93, which is larger than the cutoff point of .60 suggested by Tabachnick and Fidell (2001) for good factor analysis.

\subsubsection{Round 1}

The first round analyses revealed two factors that had an eigenvalue larger than 1 . The scree plot also showed that from the second factor on, the fractions of the total variance explained by each successive factor were dramatically reduced. The RMSEA was high for the 1-factor (0.10) solution and acceptable for 2-factor (0.07) solution. SRMR was good for both of the 1-factor (0.06) and 2-factor solutions (0.04). CFIs were larger than .90 for both 1-factor and 2 -factor solutions. $\chi^{2} / \mathrm{df}$ was smaller than 2 for both 1 -factor and 2 -factor solutions (Table 1). The result of parallel analysis indicated that only in the first factor were the eigenvalues obtained from the real data equal to or larger than those from the simulation data (Factor 1: actual eigenvalue $=67.0$, parallel $=21.8$ ).

Next, item quality was assessed with the 1-factor and 2-factor solutions. For the 1-factor solution, $73 \%$ of the items had high loadings (.60 or above) and 1 item did not load in the factor. For the 2 -factor solution, $27 \%$ of the items had high loadings (.60 or above) and $18 \%$ of the items did not load in any factors. Thirty-six percent of the items cross-loaded in two factors. The analyses demonstrated that the 1-factor solutions resulted in higher quality of items than the 2-factor solution and was therefore retained. The one item that did not load in the factor: 'I believe that I could handle the stress and the workload' (e.g. homework, projects, exams, etc. in science, technology, engineering, or math (STEM) courses at college), was deleted. Another round of factor analysis was conducted with the remaining 10 items. Goodness of fit indicators for one- and two-factor solutions are shown in Table 1.

\subsubsection{Round 2 and Round 3}

The second round analyses following similar analytic steps to the round 1 analysis revealed that both 1-factor and the 2 -factor solutions had a good model fit (see model fit indices in Table1) and an eigenvalue that was close to or larger than 1 . The 1 -factor solution was also supported by the result of parallel analysis (actual eigenvalue $=65.1$, parallel $=$ 24.0). On the other hand, scree plot supported the 2 -factor solution. When examining item quality, $80 \%$ of the items in the 1-factor solution had high loadings (above .60) while only $30 \%$ of items in the 2 -factor solution had high loadings, with $40 \%$ of items cross-loading in two factors., Therefore, the 1-factor solution was retained for further analyses. Given the conciseness and quality of the measure, two items (item 1: 'I believe that I can get good grades in my high school TECHNOLOGY-related classes'; item 2: 'I believe that I have ability to learn to use various technology tools that will help me study science, technology, engineering, or math (STEM) in college') with loadings lower than .60 were deleted. In the measure, two other items were in line with item 1 tapping into students' self-efficacy in math and science ('I believe that I can get good grades in my high school MATH classes'; 'I believe that I can get good grades in my high school SCIENCE classes'). To be consistent, these two items were also deleted. Another round of factor analysis was conducted with the remaining 6 items.

The third round analyses identified a 1-factor solution based on eigenvalues, scree plot, model fit indices (Table 1), and parallel analysis (actual eigenvalue $=80.8$, parallel $=42.2$ ). All items had high loadings (Table 2). Therefore, the 1 -factor model with 6 items was selected for the measure, which explained $67 \%$ of the total variance. 
Table 1. Goodness of fit indicators for the EFA model

\begin{tabular}{lllllllll}
\hline & $\begin{array}{l}\text { Factor } \\
\text { solution }\end{array}$ & $\mathrm{x}^{2}$ & $\mathrm{Df}$ & $\chi^{2} / \mathrm{df}$ & RMSEA & SRMR & CFI & TLI \\
\hline Round 1 & 1 & 87.29 & 44 & 1.98 & 0.10 & 0.06 & 0.91 & 0.89 \\
\cline { 2 - 8 } & 2 & 49.6 & 34 & 1.46 & 0.07 & 0.04 & 0.97 & 0.95 \\
\hline Round 2 & 1 & 62.52 & 35 & 1.79 & 0.09 & 0.05 & 0.94 & 0.92 \\
\cline { 2 - 8 } & 2 & 26.21 & 26 & 1.01 & 0.01 & 0.03 & 1 & 1 \\
\hline Round 3 & 1 & 7.51 & 9 & 0.83 & $<0.001$ & 0.02 & 1 & 1 \\
\hline
\end{tabular}

Table 2. Factor loadings of the one-factor solution

\begin{tabular}{ll}
\hline Items & Factor Loadings \\
\hline $\begin{array}{l}\text { I believe that I can make an EDUCATIONAL PLAN that will prepare me to } \\
\text { study science, technology, engineering, or math (STEM) in college. }\end{array}$ & 0.69 \\
\hline $\begin{array}{l}\text { I believe that I can CHOOSE the appropriate high school classes needed to } \\
\text { study science, technology, engineering, or math (STEM) in college if they are } \\
\text { offered at my school. }\end{array}$ & 0.75 \\
\hline $\begin{array}{l}\text { I believe that I can pass the high school classes needed to study science, } \\
\text { technology, engineering (STEM) in college. }\end{array}$ & 0.72 \\
\hline $\begin{array}{l}\text { I believe that I can get into college after high school to study science, } \\
\text { technology, engineering, or math (STEM) if I want. }\end{array}$ & 0.81 \\
\hline $\begin{array}{l}\text { I believe that I could pick the appropriate science, technology, engineering, or } \\
\text { math (STEM) courses to graduate from college. }\end{array}$ & 0.84 \\
\hline $\begin{array}{l}\text { I believe that I could earn a college degree in science, technology, engineering, } \\
\text { or math (STEM) related areas. }\end{array}$ & 0.83 \\
\hline
\end{tabular}

\section{Study 2: Confirmatory Factor Analysis}

\subsection{Method}

Confirmative factor analysis (CFA) was conducted with the revised College Going Expectancy in STEM measure using Mplus Version 6.1 (Muthen \& Muthen, 1998-2010). The purpose of CFA was to verify the proposed construct of college-going expectancy in STEM measure resulting from the previous EFA.

\subsubsection{Participants}

This study included 658 students from 31 high schools: 15 suburban, 13 urban, and 3 rural. Forty percent of the students were female, $57 \%$ of the students were male, and 3\% of the students did not report their gender. Students self-reported their ethnicity: 68\% percent of the students were White, $14.6 \%$ Hispanic or Latino, 5.9\% African American, 3.3\% Asian, 1.1\% Pacific Islander, 0.3\% American Indian or Alaska Native, and 5.8\% other. Approximately $1 \%$ did not report their ethnicity.

\subsubsection{Procedure}

Participants were administered the 6-item scale electronically. Parent consent and student assent addressing the voluntary nature and confidentiality of the study were distributed and collected prior to administration.

\subsubsection{The STEM College-Going Expectancy Measure}

The six items resulting from EFA reported in Table two were administered in Study 2. The items were rated using a 7-point Likert scale ranging from 1 (not at all true) to 7 (very true).

\subsubsection{Analytic Strategy}

The CFA in this study used an ML estimation approach to a correlation matrix. Model fit indices, including 
standardized root mean square residual (SRMR), root mean square error of approximation (RMSEA), comparative fit index (CFI), and the Tucker-Lewis index (TLI), were used as the criteria of the goodness of fit. Chi-square and $\chi^{2} / \mathrm{df}$ were also provided.

\subsection{Results}

\subsubsection{Confirmatory Factor Analysis}

The one-factor model explored in Study 1 was analyzed with CFA. The model fit indices indicated less desirable fit of the model: $\chi^{2} / \mathrm{df}$ was large; RMSEA was larger than .10. An examination of modification indexes (MI) revealed that two pairs of items were highly correlated. One pair of items was, 'I believe that I can make an educational plan that will prepare me to study science, technology, engineering, or math (STEM) in college' and, 'I believe that I can CHOOSE the appropriate high school classes needed to study science, technology, or math (STEM) in college if they are offered at my school'. The other pair was, 'I believe that I could pick the appropriate science, technology, engineering, or math (STEM) course to graduate from college' and, 'I believe that I could earn a college degree in a science-, technology-, engineering-, or math- (STEM-) related area'. The items in the first pair were both related to college preparation, so it made sense for them to be correlated. Similarly, the two items in the second pair were both related to success in college.. Correlating the two pairs resulted in a significant improvement of model fit: Chi-square was significantly decreased; $\chi^{2} / \mathrm{df}$ was close to 2 ; RSMEA decreased to .06; CFI increased to .99 (see Table 3 ).

Table 3. Goodness of fit indicators for the CFA model

\begin{tabular}{llllllll}
\hline & $\mathrm{x}^{2}$ & Df & $\chi^{2} / \mathrm{df}$ & RMSEA & SRMR & CFI & TLI \\
\hline Model 1 & 101.19 & 9 & 11.24 & 0.13 & 0.03 & 0.96 & 0.93 \\
\hline Model 2 & 25.60 & 7 & 3.66 & 0.06 & 0.02 & 0.99 & 0.98 \\
\hline
\end{tabular}

\subsubsection{Reliabilities}

Cronbach's alphas were calculated to examine the reliability of the measure in the two studies. As shown in Table 4, the alphas for the whole measure (larger than .90) indicated a high internal consistency. The alphas also remained consistent across the two studies.

Table 4. Cronbach's alphas

\begin{tabular}{ccc}
\hline \multirow{2}{*}{ Factors } & Study 1 ( $\mathrm{n}=95)$ & Study 2 $(\mathrm{n}=658)$ \\
$\alpha$ & $\alpha$ \\
\hline & .91 & .90 \\
\hline
\end{tabular}

\subsection{Comparison between Hypothesized and Observed Factors}

Based on our review of existing literature, we expected that the STEM College-Going Expectancy Scale would be a unidimensional measure including expectancy for future success items and ability belief items. This study did reveal a unidimensional scale; however, this scale involved only expectancy for future success items. The original College-Going Self-Efficacy Scale (CGSES) (Gibbons, 2005), from which our current expectancy scale was adopted, contained two subscales: (1) College attendance, and (2) College persistence. The hypothesis of Gibbons was not supported by our study when we tested the items specifically in STEM. College attendance and college persistence collapsed into one single factor.

\section{Discussion}

This study tested, developed, and validated an instrument to assess high school students' belief in their capability to attend college to study STEM and persist in college activities successfully in the future. The study modified the CGSES (Gibbons, 2005) to measure college-going expectancy in STEM learning and work in college. Our results supported the initial hypothesis that high school students perceive their college-going capability in STEM to be based on domain-specific expectancies for success. We also confirmed that high school students perceive their STEM college-going capability in terms of expectancy for success. In our study, all items measuring ability beliefs fell out of the factor. Therefore, our results do not support Wigfield and Eccles' research (2000) which showed that ability beliefs and expectancies load onto each other, but they are consistent with expectancy-value theory which 
consider the two as separate and distinctive constructs.

When the modified capabilities and decision-making items from the CGSES (Gibbons, 2005) were tested for the STEM-specific domain, items that measured expected competence in the future were found to be reliable and valid. This finding is well-aligned with the expectancies for success construct (Eccles, 1983). Since going to college is a future task for high school students, it is reasonable that the reliable and valid items in our STEM scale would measure high school students' belief in their future task capability in STEM. In the pilot study, items were included to examine both STEM ability beliefs and expectancies. Based on the exploratory factor analysis, questions pertaining to ability beliefs that measured student beliefs in their capabilities in current activities ('I believe that I can get good grades in my high school science classes' and 'I believe that I can get good grades in my high school science classes') were found to be poor items for the college-going expectancy in STEM scale and were deleted.

Similarly, the items 'I believe that I have ability to learn to use various technology tools (e.g. online text books, articles or forums, digital design, Moodle) that will help me to study science, technology, engineering, or math (STEM) in college' and 'I believe that I could handle the stress and the workload (e.g. homework, projects, exams, etc) in science, technology, engineering, or math (STEM) courses at college' did not load onto the factor and were excluded. The reason for the former item's failure may be that there are a broad range of technology tools demanding different levels of expertise; these are difficult to examine in a unified statement and may be confusing to students with limited experience in judging their expectancies for success. The latter item's failing may result from a lack of understanding of what a college workload would entail.

Questions pertaining to expectancy that assessed student beliefs about their future task outcome were found to be good items for the Scale. The items include 'I believe that I can CHOOSE the appropriate high school classes needed to study science, technology, engineering, or mathematics (STEM) in college if they are offered at my school' and 'I believe that I could pick the appropriate science, technology, engineering, or math (STEM) courses to graduate from college.' The finding that the ability belief items were not good measures of expectancy supports Eccles' (1983) expectancy-value model, which considers ability belief to be a different construct from expectancies of success, with the former focusing on current task level activities. In this study, the items measuring future tasks were found to be good items. Further, the exploratory factor analysis revealed that there was no distinction between attendance and persistence activities, but rather, they were centered on one specific domain: STEM. This supports Wigfield and Eccles' (2000) findings that ability beliefs and expectancies are likely to be domain- rather than task-specific.

\subsection{Conclusion}

Using exploratory and confirmatory factor analysis of the revised instrument, the resulting College-Going Expectancy (CGE) in STEM Scale provides evidence that the instrument is a promising measure of college-going expectancy in STEM. Overall, these findings support the distinction between expectancy for success, ability beliefs, and self-efficacy. That is, whereas ability beliefs and self-efficacy tend to measure beliefs about ability in terms of task-specific behavior to accomplish current activities (Wigfield \& Eccles, 2000; Pajares, 1996), this study supports the idea that expectancies of success are domain-specific and future-task-oriented. Due to the empirical similarity found between expectancies for success and ability beliefs, the findings point to the need to clearly distinguish between both constructs and for researchers investigating them to create assessments that are both task- and domain-specific.

The items included in the final version of the instrument emphasize the importance of proper guidance to high school students in planning STEM coursework and assistance in enhancing skill learning. Such guidance may increase both student interest in STEM domains and beliefs in their ability to pursue careers and college majors in STEM.

\subsection{Future Work}

Further research is needed to determine whether the scale can be successfully used to predict whether students will enter, stay in, or be successful in STEM fields in college. It would be particularly interesting to examine the correlations between this scale, performance in high school, and success indicators in college in STEM-related fields. Future studies are also recommended to test scale questions in each STEM subject.

\section{Acknowledgements}

This work was supported by the US Department of Education, Investing in Innovation (i3) Program \#U396C100520 and the National Science Foundation Innovative Technology Experiences for Students and Teachers (ITEST) Program \#1029472. 


\section{References}

Bandura, A. (1986). Social foundations of thought and action: A social cognitive theory. Englewood Cliffs, NJ: Prentice Hall.

Bandura, A. (1997). Self-efficacy: The exercise of control. New York: W. H. Freeman \& Co.

Bandura A., Barbaranelli, C., Caprara, G.V., \& Pastorelli, C. (1996). Multifaceted impact of self-efficacy beliefs on academic functioning. Child Development, 67, 1206-1222. http://dx.doi.org/10.2307/1131888

Bandura, A., Barbaranelli, C., Caprara, G.V., \& Pastorelli, C. (2001). Self-efficacy beliefs as shapers of children's aspirations can career trajectories. Child Development, $72(1), \quad 187-206$. http://dx.doi.org/10.1111/1467-8624.00273

Bentler, P. M. (1995). EQS structural equations program manual. Encino, CA: Multivariate Software.

Bergin, D., Cooks, H., \& Bergin, C. (2007). Effects of a college access program for youth underrepresented in higher education: A randomized experiment. Research in Higher Education, 48(6), 727-750. http://dx.doi.org/10.1007/s11162-006-9049-9

Betz, N. E. (2007). Career self-efficacy: Exemplary recent research and emerging directions. Journal of Career Assessment, 15, 403-422. http://dx.doi.org/10.1177/1069072707305759

Bong, M. (2001). Between- and within-domain relations of academic motivation among middle and high school students: Self-efficacy, task-value, and achievement goals. Journal of Educational Psychology, 93(1), 23-34. http://dx.doi.org/10.1037/0022-0663.93.1.23

Bong, M. \& Clark, R.E. (1999). Comparison between self-concept and self-efficacy in academic motivation research. Educational psychologist, 34(3), 139-153. http://dx.doi.org/10.1207/s15326985ep3403_1

Britner, S. L., \& Pajares, F. (2006). Sources of science self-efficacy beliefs of middle school students. Journal of Research in Science Teaching, 43, 485-499. http://dx.doi.org/10.1002/tea.20131

Brown, M.W., \& Cudeck, R. (1993). Alternative ways of assessing model fit. In K. A. Bollen \& J. S. Long (Eds.), Testing structural equation models (pp. 36-62). Thousand Oaks, CA: Sage.

Byars-Winston, A.M., \& Fouad, N.A. (2008). Math and science social cognitive variables in college students: Contributions of contextual factors in predicting goals. Journal of Career Assessment, 16, $425-440$. http://dx.doi.org/10.1177/1069072708318901

Byrne, B.M. (2001). Structural equation modeling with AMOS: Basic concepts, applications and programming. Mahwah, NJ: Erlbaum.

Caprara, V., Vecchione, M., Allesandri, G., Gerbino, M. \& Barbranelli, C. (2011). The contribution of personality traits and self-efficacy beliefs to academic achievement: A longitudinal study. British Journal of Educational Psychology, 81(1), 78-96. http://dx.doi.org/10.1348/2044-8279.002004

Chemers, M., Zurbriggen, E., Syed, M., Goza, B., \& Bearman, S. (2011). The role of efficacy and identity in science career commitment among underrepresented minority students. Journal of Social Issues, 67(3), 469-491. http://dx.doi.org/10.1111/j.1540-4560.2011.01710.x

Deci, E. L., \& Ryan, R. M. (1985). Intrinsic motivation and self-determination in human behavior. New York: Plenum.

Eccles, J. (1983a). Expectancies, values and academic behaviors. In J.T. Spence (ed.), Achievement and achievement motives (pp. 75-146). San Francisco: Freeman.

Eccles, J.S, \& Wigfield, A. (1995). In the mind of actor: The structure of adolescents' achievement task values and expectancy-related beliefs. Personality and Social Psychology Bulletin, 21(3), 215-225. http://dx.doi.org/10.1177/0146167295213003

Eccles, J. S., \& Wigfield, A. (2002). Motivational beliefs, values, and goals. Annual Review of Psychology, 53, 109-132. http://dx.doi.org/10.1146/annurev.psych.53.100901.135153

Fouad, N., \& Smith, L. (1997). Reliability and validity evidence for the Middle School Self-Efficacy Scale. Measurement and Evaluation in Counseling and Development, 30, 17-31.

Gibbons, M.M. (2005). College-Going Beliefs of Prospective First-Generation College Students: Perceived Barriers, 
Social Supports, Self-Efficacy and Outcome Expectations. (Doctoral dissertation, University of North Carolina Greensboro). Retrieved from http://libres.uncg.edu/ir/uncg/f/umi-uncg-1049.pdf

Gibbons, M.M., \& Borders, L. (2010). A measure of college-going self-efficacy for middle school students. Professional School Counseling, 13(4), 234-243. http://dx.doi.org/10.5330/PSC.n.2010-13.234

Gloria, A.M., Kurpius, S.E.R., Hamilton, K.D., \& Wilson, M.S. (1999). African American students' persistence at a predominantly White university: Influences of social support, university comfort, and self-beliefs. Journal of College Student Development, 40, 93 - 105.

Gore, P. A., Jr. (2006). Academic self-efficacy as a predictor of college outcomes: Two incremental validity studies. Journal of Career Assessment, 14, 92-115. http://dx.doi.org/10.1177/1069072705281367

Gorsuch, R. L. (1983). Factor analysis (2nd ed.). Hillsdale, NJ: Lawrence Erlbaum Associates.

Horn, L., \& Nunez, A. (2000). Mapping the road to college: First-generation students' math track, planning strategies, and context support (NCES Report 2000-153). Washington, DC: U.S. Department of Education, National Center for Educational Statistics.

Hu, L., \& Bentler, P.M. (1999). Cutoff criteria for fit indexes in covariance structure analysis: Conventional criteria versus new alternatives. Structural Equation Modeling, 6, 1-55. http://dx.doi.org/10.1080/10705519909540118

Jacobs, J.E. (2005). Twenty-five years of research on gender and ethnic differences in math and science career choices: What have we learned? New Directions for Child \& Adolescent Development, 110, 85-94. http://dx.doi.org/10.1002/cd.151

Jacobs, J.E., Lanza, S., Osgood, D.W., Eccles, J.S., \& Wigfield, A. (2002) Changes in children's self-competence and values: Gender and domain difference across grades one through twelve. Child Development, 73(2), 509-527. http://dx.doi.org/10.1111/1467-8624.00421

Johnson, D. R., \& Creech, J. C. (1983) Ordinal measures in multiple indicator models: A simulation study of categorization error. American Sociological Review, 48, 398-407. http://dx.doi.org/10.2307/2095231

Lackey, N. R., Sullivan, J. J. \& Pett, M.A. (2003). Making sense of factor analysis: The use of factor analysis for instrument development in health care research. Thousand Oaks, CA: Sage.

Lorenzo-Seva, U., \& Ferrando, P.J. (2011). FIRE: An SPSS program for variable selection in multiple linear regression analysis via the relative importance of predictors. Behavior Research Methods Instruments \& Computers, 43(1), 1-7. http://dx.doi.org/10.3758/s13428-010-0043-y

Majer, J. M. (2009). Self-efficacy and academic success among ethnically diverse first-generation community college students. Journal of Diversity in Higher Education, 2(4), 243-250. http://dx.doi.org/10.1037/a0017852

Marsh, H. W., Hau, K.-T., Artelt, C., Baumert, J., \& Peschar, J. L. (2006). OECD's brief self- report measure of educational psychology's most useful affective constructs: Cross-cultural, psychometric comparisons across 25 Countries. International Journal of Testing, 6(4), 311-360. http://dx.doi.org/10.1207/s15327574ijt0604_1

Muthén, L.K. \& Muthén, B.O. (1998-2010). Mplus Version 6.1 [computer software], Los Angeles, CA: Muthén and Muthén.

Nauta, M.M., Epperson, D.L., \& Kahn, J.H. (1998). A multiple-groups analysis of predictors of higher level career aspirations among women in mathematics, science, and engineering majors. Journal of Counseling Psychology, 45(4), 483-496. http://dx.doi.org/10.1037/0022-0167.45.4.483

Oesterreich, H. (2000). Characteristics of effective urban college preparation programs (Report No. EDO-UD-00-8). New York, NY: Institute for Urban and Minority Education. (ERIC Document Reproduction Service No. ED 448244).

Ormrod, J. E. (2006). Educational psychology: Developing learners $\left(5^{\text {th }}\right.$ ed.). Upper Saddle River, NJ: Pearson.

Pajares, F. (1996). Self-efficacy beliefs in academic settings. Review of Educational Research, 66(4), 543-578. http://dx.doi.org/10.3102/00346543066004543

Pajares, F., \& Johnson, M. J. (1994). Confidence and competence in writing: The role of self-efficacy, outcome expectancy, and apprehension. Research in the Teaching of English, 313-331.

Pajares, F., \& Miller, M.D. (1995). Mathematics self-efficacy and mathematics performances: The need for specificity of assessment. Journal of Counseling Psychology, 42(2), 190. 
http://dx.doi.org/10.1037/0022-0167.42.2.190

Pajares, F., \& Schunk, D.H. (2001). Self-beliefs and school success: Self-efficacy, self-concept, and school achievement. In R. Riding \& S. Rayner (Eds.), International Perspectives on Individual Differences: Self-Perception, (Vol. 2, pp. 239-265). Westport, CT: Ablex.

Pintrich, P.R. (2003) A motivational science perspective on the role of student motivation in learning and teaching contexts. Journal of Educational Psychology, 95(4), 667-686. http://dx.doi.org/10.1037/0022-0663.95.4.667

Pintrich, P. R., \& Schunk, D. H. (2002). Motivation in education: Theory, research, and applications ( ${ }^{\text {nd }}$ ed.). Columbus, OH: Merrill-Prentice Hall.

Pintrich, P.R., Smith, D.A.F., Garcia, T., \& McKeachie, W. J. (1991). A manual for the use of the Motivated Strategies for Learning Questionnaire (MSLQ). Ann Arbor, MI: The Regents of the University of Michigan.

Riegle-Crumb, C., Moore, C., \& Ramos-Wada, A. (2011). Who wants to have a career in science or math? Exploring adolescents' future aspirations by gender and race/ethnicity. Science Education, 95(3), 458-476. http://dx.doi.org/10.1002/sce.20431

Robbins, S. B., Lauver, K., Le, H., Davis, D., Langley, R., \& Carlstrom, A. (2004). Do psychosocial and study skill factors predict college outcomes? A meta-analysis. Psychological Bulletin, 130(2), 261-288. http://dx.doi.org/10.1037/0033-2909.130.2.261

Schunk, D. H., Pintrich, P. R., \& Meece, J. L. (2007). Motivation in education: Theory, research, and applications ( $3^{\text {rd }}$ ed.). Upper Saddle River, NJ: Pearson/Merrill Prentice Hall.

Shell, D.F., Colvin, C., \& Bruning, R.H. (1995). Self-efficacy, attribution, and outcome expectancy mechanisms in reading and writing achievement: Grade-level and achievement-level differences. Journal of Educational Psychology, 87(3), 386-398. http://dx.doi.org/10.1037/0022-0663.87.3.386

Silvera, D., Martinussen, M., \& Dahl, T. I. (2001). The Tromsø Social Intelligence Scale, a self-report measure of social intelligence. Scandinavian Journal of Psychology, 42, 313-319. http://dx.doi.org/10.1111/1467-9450.00242

Simpkins, S. D., Davis-Kean, P. E., \& Eccles, J. S. (2006). Math and science motivation: A longitudinal examination of links between choices and beliefs. Developmental Psychology, 42(1), 70-83. http://dx.doi.org/10.1037/0012-1649.42.1.70

Solberg, V.S., O’Brien, K., Villareal, P., Kennel, R., \& Davis, B. (1993). Self-efficacy and Hispanic college students: Validation of the College Self-Efficacy Instrument. Hispanic Journal of Behavioral Sciences, 15, 80-95. http://dx.doi.org/10.1177/07399863930151004

Syed, M., Azmitia, M., \& Cooper, C. R. (2011). Identity and academic success among underrepresented ethnic minorities: An interdisciplinary review and integration. Journal of Social Issues, 67 (3), 442-468. http://dx.doi.org/10.1111/j.1540-4560.2011.01709.x

Tabachnick, B.G., \& Fidell, L.S. (2001). Using multivariate statistics $\left(4^{\text {th }}\right.$ ed.). Boston, MA: Allyn \& Bacon.

Timmerman, M.E., \& Lorenzo-Seva, U. (2011). Dimensionality assessment of ordered polytomous items with parallel analysis. Psychological Methods, 16, 209-220. http://dx.doi.org/10.1037/a0023353

Warburton, E.C., Bugarin, R., Nunez, A., \& Carroll, C.D. (2001). Bridging the gap: Academic preparation and postsecondary success of first-generation students (NCES Report 2001-153). Washington, DC: U.S. Department of Education, National Center for Educational Statistics.

Watt, H.M., Shapka, J.D., Morris, Z.A., Durik, A.M., Keating, D.P., \& Eccles, J.S. (2012). Gendered motivational processes affecting high school mathematics participation, educational aspirations, and career plans: a comparison of samples from Australia, Canada, and the United States. Developmental Psychology, 48(6), 1594-1611. http://dx.doi.org/10.1037/a0027838

Wigfield, A., \& Eccles, J. (1992). The development of achievement task values: A theoretical analysis. Developmental Review, 12, 265-310.

Wigfield, A. (1994). Expectancy-value theory of achievement motivation: A developmental perspective. Educational Psychology Review, 6(1), 49-78. http://dx.doi.org/10.1007/BF02209024

Wigfield, A., \& Eccles, J. S. (2000). Expectancy value theory of achievement motivation. Contemporary Educational Psychology, 25(1), 68-8. http://dx.doi.org/10.1006/ceps.1999.1015 
Wigfield, A., Tonks, S., \& Klauda, S. L. (2009). Expectancy-value theory. In K. R. Wentzel \& A. Wigfield (Eds.), Handbook of motivation at school (pp. 55-75). New York, NY: Routledge.

Witkow, M. R., \& Fuligni, A. J. (2011). Ethnic and generational differences in the relations between social support and academic achievement across the high school years. Journal of Social Issues, 67(3), 531-552. http://dx.doi.org/10.1111/j.1540-4560.2011.01713.x

Zimmerman, B. J. (2000). Self-efficacy: An essential motive to learn. Contemporary Educational Psychology, 25(1), 82-91. http://dx.doi.org/10.1006/ceps.1999.1016

\section{Notes}

Note 1. Conventionally, SRMR smaller than .05, RMSEA smaller than .06, CFI larger than .96, and TLI larger than .95 are considered to be a good fit (Hu \& Bentler, 1999), while SRMR smaller than .08, RMSEA smaller than .1, CFI larger than .90, and TLI larger than .90 are considered to be an acceptable fit (Brown \& Cudeck, 1993). The value of Chi-square was also provided; however, Chi-squares are often biased by sample size. Therefore, $\chi^{2} / \mathrm{df}$ was calculated and a value close to 2 indicated a good fit of the model (Bentler 1995; Byrne 2001). In parallel analysis, a factor should be retained when its eigenvalue obtained from the real data is equal to or larger than the one from the simulation data (Timmerman \& Lorenzo-Seva, 2011). 